described which show that electrified fencing is likely to prove a simple and effective method of control, while at the same time it gives a cash saving of $80-90$ per cent over the ordinary post and wire type. Methods for making silage from grass mowings have been investigated with very satisfactory results. Information is supplied as to how the grass can be collected, the type of silos to use and precisely how they should be filled. Young grass mowings are so nutritious that a really valuable contribution to the country's feeding-stuffs could be made in this way. If silage-making is not practicable, the grass mowings need not be wasted, but can be either composted for manure or dried for cattle feeding. An appeal is made to former subscribers for their continued support, as this is essential if the Research Station is to be in a position to fulfil its normal functions directly the War is over.

\section{Certificate in Natural History}

A NEw edition of the emergency regulations for the certificate of proficiency in natural history has just been issued by the University of London. The work, which has been specially designed to take advantage of the fact that large numbers of teachers are, owing to war conditions, presented with a unique opportunity of natural history study in the field, involves a directed course of private reading at home, attendance at a practical laboratory course of two weeks duration in the summer vacation, an approved plan of field-work suited to the student's locality to be written up in the form of an essay, and examination. Definite arrangements have not yet been made, but it is hoped that the practical course this year will be held at the Royal Holloway College, Englefield Green, Surrey, during July 26-August 8. Copies of the regulations and further information may be obtained from the University Extension Registrar, University of London, at Richmond College, Richmond, Surrey.

\section{Diagrams and Formulæ for Lantern Slides}

Prof. A. C. Chibnall, of the Imperial College of Science and Technology, London, has utilized 'Cellophane' and 'carbon' paper for the preparation, without photography, of lantern slides of line diagrams and chemical formulæ. Mr. J. W. Minnis, of the Chemistry Department, Heriot-Watt College, Edinburgh, states that he has obtained good results with two lantern-slide cover-glasses. A piece of typewriter 'carbon' paper is placed on one and the required diagrams or formulæ are drawn on the back of the 'carbon' paper, using a glass rod pulled to a point. The paper is removed, the second cover-glass placed over the carbon image, and the two glasses bound together in the usual manner. The resulting slide gave good reproduction in the lantern.

\section{Synthetic Rubber Production in Canada}

Mr. Howe, the Dominions Minister of Munitions, has announced the establishment of a Governmentowned company called the Polymer Corporation, Lid., with headquarters in Toronto, which will undertake the production in Canada of synthetic rubber of the Buna type. According to the Ottawa correspondent of The Times, Mr. Howe said that four plants would probably be required for the three stages of the manufacturing process to be employed. The output, when the plants are working at full capacity, is expected to be about 34,000 tons a year, but production cannot begin before the end of 1943. Colonel Arthur L. Bishop, a prominent Toronto industrialist, has been appointed president of the Corporation, and there are four other directors.

\section{Announcements}

Mr. R. A. ButLer, president of the Board of Education, is to be chairman of the Scientific Advisory and Engineering Advisory Committees in succession to Lord Hankey.

SIR JoHn GREenLy was elected president for $1942-43$ of the Institute of Metals at the annual general meeting held on March 11.

THe Committee of the Athenæum has elected the following gentlemen, under the provisions of Rule II of the Club, which empowers the annual election by the Committee of a certain number of persons of distinguished eminence in science, literature, or the arts, or for their public services: Prof. P. M. S. Blackett, Langworthy professor of physies, University of Manchester; Mr. 'T. D. Kendrick, keeper of British and Medireval Antiquities, British Museum; Mr. J. M. Keynes, economist, and fellow and bursar of King's College, Cambridge.

THE following appointments in the Colonial Service have recently been made: S. R. Payne, assistant conservator of forests, Gold Coast ; C. B. Garnett (senior agricultural officer, Zanzibar), senior agricultural officer, Nyasaland.

The conference on "European Agriculture : Scientific Problems in Post-war Reconstruction", arranged by the Division for the Social and International Relations of Science of the British Association, and postponed from March 13-14 owing to the death of Sir William Bragg, will be held on March 20-21 at the London School of Hygiene and Tropical Medicine, Keppel Street, W.C.l, with sessions at 10.15 a.m. and 2.15 p.m. on each day as previously arranged, and the programme, so far as possible, unaltered. Fresh tickets will not be issued.

THe Science Faculty of the Marx Memorial Library and Workers' School has arranged symposia on "Science and Technology in the Soviet Union" and the "Scientific Attitude to Fascism, with particular reference to Racial Theories", to be held at the London School of Hygiene and Tropical Medicine on April 5 and 6. Papers at the first symposium will include those by Prof. J. D. Bernal, Mr. Eric Godfrey, Dr. Norman Henry, Mrs. B. King, Dr. J. Needham, Mr. H. Rose, Dr. M. Ruhemann and Mr. H. P. Vowles. Those for the second symposium include the following authors: Prof. J. B. S. Haldane, Dr. C. F. D. Hawkes, Dr. P. Gorer, Prof. H. Levy, Dr. G. M. Morant and Mrs. Dona Torr. Further information can be obtained from the secretary, Faculty of Science, Marx House, Clerkenwell Green, London, E.C.1.

Errata. The May Lecture of the Institute of Metals is to be delivered on May 13, not May 31 as stated in NATURE of March 14, p. 299.

In Nature of February 28, p. 243, under "Night Sky in March" the word "occultations" of the planets was inadvertently used for "conjunctions". 